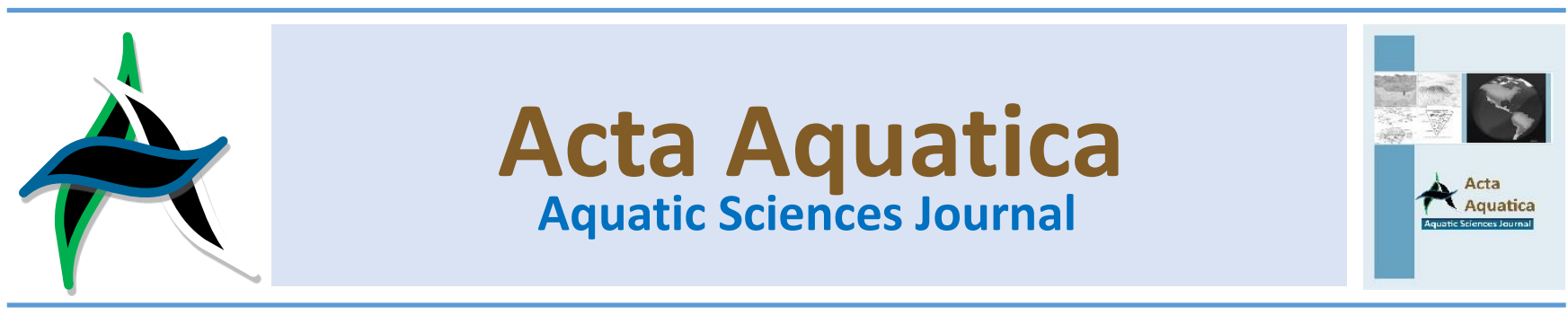

\title{
Adaptasi waktu pencahayaan sebagai strategi peningkatan pertumbuhan ikan bawal air tawar (Colossoma macropomum)
}

\section{Photoperiod adaptation as a strategy to improve the growth rate of pomfret fish (Colossoma macropomum)}

\author{
Suri Purnama Febri ${ }^{a} *$, Antoni ${ }^{a}$, Riza Rasuldi ${ }^{a}$, Agustinus Sinanga ${ }^{a}$, Teuku Fadlon Haser ${ }^{a}$, Muhammad Syahril ${ }^{b}$ dan \\ Suraiya Nazlia ${ }^{c}$
}

a Program Studi Akuakultur, Fakultas Pertanian, Universitas Samudra. Aceh, Indonesia

${ }^{b}$ Program Studi Agroteknologi, Fakultas Pertanian, Universitas Samudra. Aceh, Indonesia

c Program Studi Budidaya Perairan, Fakultas Perikanan, Universitas Abulyatama. Aceh, Indonesia

\begin{abstract}
Abstrak
Penelitian ini bertujuan untuk mengetahui tingkat pertumbuhan ikan bawal yang diberi perlakuan cahaya pada malam hari. Metode yang digunakan pada penelitian ini adalah metode eksperimental dengan 4 perlakuan dan 3 ulangan. Pada setiap perlakuan dengan waktu pencahayaan selama $\mathrm{P} 1=12$ jam, $\mathrm{P} 2=16$ jam, P3=20 jam, dan P4=24 jam. Hasil dari perlakuan tersebut berpengaruh nyata terhadap laju pertumbuhan, bobot mutlak, panjang mutlak, dan rasio konversi pakan (FCR). Sedangkan pada sintasan tidak memiliki perbedaan yang signifikan. Laju pertumbuhan harian tertinggi terdapat pada P4 sebesar $5,30 \%$, sedangkan laju pertumbuhan yang terendah terdapat pada P1 sebesar $4,47 \%$. Berat mutlak tertinggi didapat pada P4 sebesar $25,40 \mathrm{~g}$, sedangkan berat mutlak terendah pada P1 sebesar $17,91 \mathrm{~g}$. Selanjutnya pada parameter panjang mutlak yang tertinggi juga pada P4 sebesar $4,66 \mathrm{~cm}$, sedangkan yang terendah pada perlakuan $\mathrm{P} 1$ sebesar $3,66 \mathrm{~cm}$. Pada rasio konversi pakan memiliki nilai tertinggi pada P1 sebesar $1,69 \pm 0,02$ dan terendah pada $\mathrm{P} 2$ sebesar $1,45 \pm 0,12$. Dari hasil perekayasaan dengan waktu pencahayaan pada lingkungan budidaya, semakin lama waktu pencahayaan yang diberikan maka pertumbuhan yang dihasilkan memiliki kategori semakin baik.
\end{abstract}

Kata kunci: ikan bawal; lampu pijar; pertumbuhan; rekayasa cahaya

\begin{abstract}
This study aims to determine the growth rate of pomfret, which is treated with light at night. The method used in this study is an experimental method with 4 treatments and 3 replications. At each treatment with lighting times for P1 $=12$ hours, P2 = 16 hours, P3 $=20$ hours, and P4 $=24$ hours. The results of these treatments significantly influence the growth rate, absolute weight, absolute length, and feed conversion ratio (FCR), whereas the survival does not have a significant difference. The highest daily growth rate is in P4 of $5.30 \%$, while the lowest growth rate is at $\mathrm{P} 1$ of $4.47 \%$. The highest total weight in $\mathrm{P} 4$ of $25,40 \mathrm{~g}$, while the lowest total weight at $\mathrm{P} 1$ is $17.91 \mathrm{~g}$. Furthermore, the highest absolute parameter is $\mathrm{P} 4$ of $4.66 \mathrm{~cm}$, while the lowest in the first step is $3.66 \mathrm{~cm}$. The feed conversion ratio has the highest value at $P 1$ at $1.69 \pm 0.02$ and the lowest at $\mathrm{P} 2$ at $1.45 \pm 0.12$. From the results of engineering with the lighting time in the aquaculture environment, the longer the lighting time is given, the better the resulting growth has been.
\end{abstract}

Keywords: pomfret; incandescent bulbs; growth; light modification

\section{Pendahuluan}

Ikan bawal (Colossoma macropomum) memiliki pertumbuhan yang sangat lambat. Ikan bawal merupakan salah satu komoditas yang banyak dibudidayakan dan diminati oleh masyarakat, sehingga dapat dikatakan komoditas unggulan dalam bidang budidaya perikanan air tawar. Ikan bawal lebih aktif mencari makan pada siang hari (diurnal), sedangkan pada

\footnotetext{
* Korespondensi penulis: Program Studi Akuakultur, Fakultas Pertanian Universitas Samudera. Kota Langsa, Provinsi Aceh, Indonesia.

Telp: +6285260531466

e-mail: suripurnamafebri@unsam

doi: https://doi.org/10.29103/aa.v7i2.2509
} 
malam hari lebih banyak diam (Djarijah, 2001). Dari sifat diurnal yang dimiliki oleh ikan bawal, dapat dilakukan rekayasa lingkungan budidaya dengan memberikan intensitas cahaya untuk membuat lingkungan terlihat seperti di siang hari. Dilakukannya rekayasa tersebut bertujuan untuk membuat metabolisme ikan meningkat dan dapat dilakukan pemberian pakan pada malam hari sehingga pertumbuhan ikan bawal diharapkan lebih cepat.

Ikan bawal mempunyai kemampuan melihat pada waktu siang hari dengan kekuatan penerangan sampai ratusan ribu lux. Pada keadaaan hampir gelap menunjukkan bahwa kuat penerangan erat kaitannya dengan tingkat sensitivitas penglihatan ikan. Berkurangnya derajat penerangan akan menyebabkan berkurangnya jarak penglihatan ikan sehingga akan kesulitan dalam mencari makan untuk kebutuhan hidupnya (Syam \& Satria, 2009).

Dari adanya cahaya yang diberikan terhadap ikan, membuat respon hormon. Hormon merupakan salah satu faktor penting yang dapat menjadi perhatian pembudidaya dalam meningkatkan produktivitas perikanan. Respon ikan terhadap hormon dapat menjadi alternatif yang tepat untuk menunjang pertumbuhan. Salah satu respon hormon yang dapat berfungsi dalam pertumbuhan dan reproduksi adalah cahaya.

Respon cahaya terhadap ikan secara positif dapat meningkatkan nafsu makan ikan sehingga proses respirasi dapat meningkat yang mendorong ikan berselera untuk makan dan menjadi salah satu pendukung penting dalam pertumbuhan (Setyawan et al., 2014). Menurut (Boeuf et al., 1999), adanya cahaya dapat mempengaruhi laju konsumsi makan ikan sehingga merangsang pertumbuhan ikan. Cahaya juga dapat mempengaruhi tingkah laku, sintasan dan metabolisme ikan (Chengguo, 2009). Intensitas cahaya yang cukup, spectrum cahaya dan lama pencahayaan memiliki pengaruh yang signifikan pada setiap tahapan kehidupan ikan (Wirawan, 2015).

\section{Bahan dan metode}

Penelitian dilaksanakan pada bulan April-Mei 2019. Penelitian ini menggunakan rancangan acak lengkap (RAL), terdiri dari 4 perlakuan masing-masing tiga kali ulangan sehingga diperoleh 12 satuan percobaan. Ikan bawal yang di uji yaitu benih ikan bawal dengan ukuran 5-6 cm, dengan kepadatan 5 ekor per wadah. Jumlah benih ikan bawal yang dibutuhkan yaitu sebanyak 120 ekor, 60 ekor digunakan untuk penelitian dan sisanya sebanyak 60 ekor sebagai ikan stok.

Pakan yang digunakan adalah pakan buatan berupa pelet. Pakan ini biasa digunakan untuk benih ikan bawal dengan kandungan protein $39-40 \%$. Selama masa pemeliharaan, benih ikan bawal diberikan pakan dengan tingkat pemberian pakan sebanyak $3 \%$ dari bobot total ikan dan frekuensi pemberian pakan 4 kali per hari pada selang waktu selama 6 jam sekali. Kualitas air dilakukan pengecekan dan disesuaikan dengan toleransi hidup dan pertumbuhan ikan bawal. Selanjutnya intensitas cahaya yang diberikan pada setiap perlakuan yaitu dengan menggunakan lampu pijar 10-watt dengan intensitas 314 lux.

\subsection{Pengukuran bobot mutlak dan panjang mutlak ikan bawal}

Pengukuran bobot tubuh dilakukan untuk mengetahui pertambahan bobot tubuh ikan selama penelitian. Bobot tubuh benih ikan bawal yang dipelihara diperoleh dengan cara menimbang benih ikan menggunakan timbangan digital. Pengukuran bobot tubuh awal dilakukan sebelum ikan mulai diberi perlakuan. Bobot tubuh ikan yang akan diteliti harus memiliki ukuran tubuh yang seragam yaitu pada kisaran 4-5 gram. Setelah diberi perlakuan cahaya, kemudian dilihat apakah metabolisme ikan yang aktif disiang hari dapat juga aktif pada malam hari, dengan adanya rekayasa lingkungan yang diberikan sehingga frekuensi makan ikan bertambah dan menunjang laju pertumbuhan yang lebih cepat.

Pengukuran bobot tubuh dilakukan setiap sepuluh hari sekali dalam jangka waktu penelitian selama 40 hari untuk mengetahui bobot tubuh setiap sampling yang digunakan sebagai acuan dalam pemberian pakan sebanyak $3 \%$ dari bobot tubuh ikan. Pengukuran bobot mutlak tubuh dapat dihitung dengan menggunakan rumus (Zonneveld et al., 1991 dalam Kurniawan, 2017) sebagai berikut:

$$
\mathrm{G}=\mathrm{W}_{\mathrm{t}}-\mathrm{W}_{0}
$$

Keterangan:

$\mathrm{G}$ = Pertumbuhan bobot mutlak (g)

$\mathrm{W}_{\mathrm{t}}=$ Bobot akhir $(\mathrm{g})$

$\mathrm{W}_{0}=$ Bobot awal (g)

Pengukuran panjang mutlak ikan juga merupakan salah satu indikator dalam pertumbuhan ikan, untuk mengetahui panjang mutlak ikan dapat dilakukan dengan melakukan sampling yang telah ditentukan yaitu setiap tujuh hari sekali dalam waktu pemeliharaan selama 40 hari. Pengukuran panjang mutlak diawali dengan mengukur panjang ikan menggunakan mistar. Dalam melakukan penghitungan panjang mutlak ikan dapat dilakukan dengan menggunakan rumus, sebagai berikut:

$$
P=W t-W_{0}
$$

Keterangan :

$\mathrm{P}=$ Pertumbuhan panjang mutlak $(\mathrm{cm})$

$\mathrm{W}_{\mathrm{t}}=$ Pertumbuhan panjang benih pada akhir penelitian $(\mathrm{cm})$

$\mathrm{W}_{0}=$ Pertumbuhan panjang benih pada awal penelitian $(\mathrm{cm})$

\subsection{Laju pertumbuhan harian}

Laju pertumbuhan ikan sangat dipengaruhi oleh jumlah pemberian, frekuensi pemberian, dan kualitas pakan yang diberikan kepada ikan serta kondisi lingkungan yang sesuai dengan habitat dari hidup ikan bawal. Kecepatan laju pertumbuhan dapat diukur melalui pertambahan bobot tubuh dengan cara mengukur dan menimbang ikan bawal yang diteliti berdasarkan satuan waktu yang ditentukan (Amalia, 2019). Hal ini berkaitan dengan adanya tingkat pertumbuhan ikan bawal yang diberikan perlakuan, sehingga laju pertumbuhan benih ikan bawal yang dipelihara dapat diketahui dengan melakukan penghitungan menggunakan rumus (Effendi, 1997) berikut:

$$
\mathrm{LPH}=\frac{(\mathrm{LnWt}-\mathrm{LnWo})}{\mathrm{t}} \times 100 \%
$$

Keterangan :

$\mathrm{LPH} \quad=$ Pertumbuhan harian (\%)

$\mathrm{LnW}_{\mathrm{t}}=$ Bobot rata-rata akhir pemeliharaan $(\mathrm{g})$

$\mathrm{LnW}_{\mathrm{o}}=$ Bobot rata-rata awal pemeliharaan $(\mathrm{g})$

$\mathrm{t} \quad=$ Waktu pemeliharaan (hari)

\subsection{Rasio konversi pakan}

Pakan merupakan salah satu faktor yang berperan penting dalam pertumbuhan ikan. Jumlah pakan yang diberikan pada ikan harus sesuai dengan kebutuhan ikan, hal ini diharapkan dengan adanya pemberian pakan yang tepat maka 
dapat menaikkan bobot dari tubuh ikan yang dipelihara (Effendi, 2004). Rasio konversi pemberian pakan dapat dihitung menggunakan rumus berikut (Khordik, 2005):

$$
F C R=\frac{F}{(W t+D)-W o}
$$

Keterangan :

$\mathrm{FCR}=$ Rasio konversi pemberian pakan

$\mathrm{F} \quad=$ Jumlah pakan yang diberikan selama pemeliharaan (g)

$\mathrm{Wt}=$ Berat total ikan diakhir pemeliharaan $(\mathrm{g})$

Wo = Berat total ikan diawal pemeliharaan (g)

$\mathrm{D} \quad=$ Berat total ikan yang mati $(\mathrm{g})$

\subsection{Sintasan (tingkat kelangsungan hidup)}

Sintasan merupakan perbandingan antara jumlah organisme yang hidup pada akhir suatu periode dengan jumlah organisme yang hidup pada awal periode. Perhitungan sintasan memiliki tujuan untuk melihat keberhasilan terhadap suatu budidaya, yaitu untuk mengetahui seberapa besar persentase ikan yang dapat hidup selama berlangsungnya budidaya. Menurut (Effendi, 1997), sintasan benih ikan bawal dapat dihitung dengan menggunakan rumus yaitu :

$$
\mathrm{Sn}=\frac{\mathrm{Nt}}{\mathrm{No}} \times 100 \%
$$

Keterangan :

$\mathrm{Sn}=$ Kelangsungan Hidup (\%)

$\mathrm{N}_{\mathrm{t}}=$ Jumlah ikan pada akhir penelitian (ekor)

$\mathrm{N}_{\mathrm{o}}=$ Jumlah ikan pada awal pemeliharaan (ekor)

\section{Hasil dan pembahasan}

Hasil pengamatan berat mutlak ikan bawal yang diberi perlakuan pencahayaan dapat dilihat pada Tabel 1 . Berat mutlak yang tertinggi didapatkan pada perlakuan P4 dengan pencahayaan selama 24 jam sebesar $25,40 \pm 5,29 \mathrm{~g}$, sedangkan berat mutlak terendah pada perlakuan $\mathrm{P} 1$ dengan pencahayaan selama 12 jam sebesar $17,91 \pm 3,03 \mathrm{~g}$.

Hasil analisis menunjukkan terdapat perbedaan signifikan berat mutlak ikan bawal yang diberi perlakuan pencahayaan $(p<0,05)$. Setelah dilakukan uji Duncan, perlakuan terbaik didapatkan pada P4 dengan pencahayaan selama 24 jam.

Tabel 1

Berat mutlak ikan bawal yang diberi perlakuan pencahayaan (dalam gram).

\begin{tabular}{ccccc}
\hline \multirow{2}{*}{ Ulangan } & \multicolumn{4}{c}{ Waktu pencahayaan (jam) } \\
\cline { 2 - 5 } & P1 (12 jam) & P2 (16 jam) & P3 (20 jam) & P4 (24 jam) \\
\hline 1 & 18,40 & 19,60 & 22,20 & 25,50 \\
2 & 18,65 & 19,60 & 20,80 & 27,20 \\
3 & 16,70 & 20,90 & 21,10 & 23,50 \\
\hline Rerata \pm sd & $17,91 \pm 1,06^{\mathrm{c}}$ & $20,03 \pm 0,75^{\mathrm{b}}$ & $21,36 \pm 0,74^{\mathrm{b}}$ & $25,40 \pm 1,85^{\mathrm{a}}$ \\
\hline
\end{tabular}

Keterangan: Angka-angka yang diikuti oleh huruf yang sama, tidak berbeda nyata menurut uji jarak berganda duncan (DMRT) pada $\alpha=5 \%$.

Hasil pengamatan panjang mutlak ikan bawal yang diberi perlakuan pencahayaan dapat dilihat pada Tabel 2 . Panjang mutlak ikan bawal tertinggi diperoleh pada P4 dengan lama pencahayaan selama 24 jam dengan nilai sebesar $4,66 \pm 5,29 \mathrm{~cm}$, sedangkan panjang mutlak terendah adalah pada $\mathrm{P} 1$ dengan pencahayaan selama 12 jam sebesar $3,66 \pm 3,03 \mathrm{~cm}$. Hasil analisis menunjukkan terdapat perbedaan signifikan antara pemberian waktu pencahayaan terhadap panjang mutlak ikan bawal $(p<0,05)$. Setelah dilakukan uji jarak berganda duncan didapatkan bahwa perlakuan terbaik didapat pada perlakuan P4 dengan pencahayaan selama 24 jam.

Tabel 2

Panjang mutlak ikan bawal yang diberi perlakuan pencahayaan (dalam $\mathrm{cm}$ ).

\begin{tabular}{ccccc}
\hline \multirow{2}{*}{ Ulangan } & \multicolumn{4}{c}{ Waktu pencahayaan (jam) } \\
\cline { 2 - 5 } & P1 (12 jam) & P2 (16 jam) & P3 (20 jam) & P4 (24 jam) \\
\hline 1 & 3,6 & 4,2 & 4,7 & 4,7 \\
2 & 3,7 & 4,5 & 4,4 & 5,2 \\
3 & 3,7 & 4,8 & 4,5 & 4,1 \\
\hline Rerata \pm sd & $3,66 \pm 3,03^{\mathrm{a}}$ & $4,50 \pm 2,14^{\mathrm{a}}$ & $4,53 \pm 2,11^{\mathrm{a}}$ & $4,66 \pm 5,29^{\mathrm{b}}$ \\
\hline
\end{tabular}

Keterangan: Angka-angka yang diikuti oleh huruf yang sama, tidak berbeda nyata menurut uji jarak berganda duncan (DMRT) pada $\alpha=5 \%$

Dari pengamatan laju pertumbuhan harian dan analisis, hasil menunjukkan bahwa perlakuan dengan lama pencahayaan berpengaruh nyata terhadap parameter laju pertumbuhan harian ikan bawal. Rata-rata dari laju pertumbuhan harian yang diberi perlakuan lama pencahayaan dapat dilihat pada Tabel 3 .

Hasil penelitian menunjukkan laju pertumbuhan ikan bawal dari perlakuan P1 dengan waktu pencahayaan selama 12 jam sampai perlakuan $\mathrm{P} 4$ dengan waktu pencahayaan selama 24

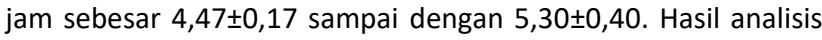
menunjukkan bahwa terdapat perbedaan signifikan antara pemberian waktu pencahayaan terhadap laju pertumbuhan harian ikan bawal $(p<0,05)$. Setelah dilakukan uji jarak berganda duncan perlakuan yang memiliki respon paling baik adalah pada P4 dengan waktu pencahayaan 24 jam.

Tabel 3

Laju pertumbuhan harian ikan bawal yang diberi perlakuan pencahayaan.

\begin{tabular}{ccccc}
\hline \multirow{2}{*}{ Ulangan } & \multicolumn{4}{c}{ Waktu pencahayaan (jam) } \\
\cline { 2 - 5 } & P1 (12 jam) & P2 (16 jam) & P3 (20 jam) & P4 (24 jam) \\
\hline 1 & 4,50 & 4,85 & 5,14 & 5,17 \\
2 & 4,63 & 4,74 & 4,78 & 5,75 \\
3 & 4,28 & 4,89 & 5,02 & 4,97 \\
\hline Rerata & $4,47 \pm 0,17^{\mathrm{b}}$ & $4,83 \pm 0,08^{\mathrm{b}}$ & $4,98 \pm 0,18^{\mathrm{a}}$ & $5,30 \pm 0,40^{\mathrm{a}}$ \\
\hline
\end{tabular}

Keterangan: Angka-angka yang diikuti oleh huruf yang sama, tidak berbeda nyata menurut uji jarak berganda duncan (DMRT) pada $\alpha=5 \%$.

Berdasarkan perhitungan rasio konversi pakan dan analisis yang telah dilakukan, hasil analisis menunjukkan bahwa perlakuan waktu pencahayaan berpengaruh nyata terhadap parameter rasio konversi pakan yang diberikan pada ikan selama penelitian $(p<0,05)$. Nilai rasio konversi pakan dari setiap perlakuan dapat dilihat pada Tabel 4 . Nilai rasio terendah terdapat pada P4 dan tertinggi pada P1 $(1,45 \pm 0,12$ dan $1,69 \pm 0,02)$.

Tabel 4

Rasio konversi pakan ikan bawal yang diberi perlakuan pencahayaan.

\begin{tabular}{ccccc}
\hline \multirow{2}{*}{ Ulangan } & \multicolumn{4}{c}{ Waktu pencahayaan (jam) } \\
\cline { 2 - 5 } & $\mathrm{P} 1(12$ jam) & $\mathrm{P} 2(16$ jam) & $\mathrm{P} 3(20$ jam) & P4 (24 jam) \\
\hline 1 & 1,67 & 1,64 & 1,41 & 1,51 \\
2 & 1,67 & 1,66 & 1,53 & 1,31 \\
3 & 1,71 & 1,52 & 1,51 & 1,54 \\
\hline Rerata \pm sd & $1,69 \pm 0,02^{\mathrm{b}}$ & $1,61 \pm 0,07^{\mathrm{b}}$ & $1,48 \pm 0,06^{\mathrm{b}}$ & $1,45 \pm 0,12^{\mathrm{a}}$ \\
\hline
\end{tabular}

Keterangan: Angka-angka yang diikuti oleh huruf yang sama, tidak berbeda nyata menurut uji jarak berganda duncan (DMRT) pada $\alpha=5 \%$.

Diketahui sebelumnya, semakin kecil nilai rasio konversi pakan maka akan semakin baik bagi budidaya karena akan semakin sedikit modal yang dikeluarkan untuk pengadaan pakan. Sedangkan nilai rasio yang besar akan membutuhkan biaya yang lebih dalam pengadaan pakan (Sulawesty et al., 2014). Berdasarkan uji jarak berganda duncan, didapatkan bahwa P4 dengan pencahayaan selama 24 jam merupakan 
perlakuan terbaik bagi rasio konversi pakan yang diberikan pada ikan bawal selama penelitian.

Sintasan merupakan suatu ukuran yang dapat digunakan untuk mengetahui seberapa besar toleransi dan kemampuan ikan untuk hidup selama berlangsungnya pemeliharan. Berdasarkan pengamatan sintasan yang dilakukan selama penelitian dan analisis menunjukkan hasil bahwa perlakuan waktu pencahayaan tidak berpengaruh nyata terhadap sintasan ikan bawal. Dari nilai rata-rata yang terdapat pada Tabel 5 menunjukkan bahwa waktu pencahayaan tidak memiliki perbedaan yang signifikan terhadap tingkat kelangsungan hidup.

Tabel 5

Tingkat kelangsungan hidup ikan bawal yang diberi perlakuan pencayaahan (dalam $\%)$.

\begin{tabular}{ccccc}
\hline \multirow{2}{*}{ Ulangan } & \multicolumn{4}{c}{ Lama Pencahayaan yang diberikan (Jam) } \\
\cline { 2 - 5 } & $\mathrm{P} 1(12$ jam) & P2 (16 jam) & P3 (20 jam) & P4 (24 jam) \\
\hline 1 & 100 & 100 & 100 & 100 \\
2 & 100 & 100 & 80 & 100 \\
3 & 80 & 80 & 100 & 100 \\
\hline Rerata \pm sd & $93,33 \pm 11,55^{\mathrm{a}}$ & $93,33 \pm 11,55^{\mathrm{a}}$ & $93,33 \pm 11,55^{\mathrm{a}}$ & $100 \pm 0,00^{\mathrm{a}}$ \\
\hline
\end{tabular}

Keterangan: Angka-angka yang diikuti oleh huruf yang sama, tidak berbeda nyata menurut uji jarak berganda duncan (DMRT) pada $\alpha=5 \%$.

Adanya pertambahan bobot, memiliki beberapa syarat yang harus terpenuhi diantaranya adalah pemberian pakan secara intensif, kualitas air yang terjaga, dan kondisi dari lingkungan dan wadah atau tempat pemeliharaan yang sesuai dengan padat tebar ikan (Taufiq et al., 2016). Pada penelitian ini sudah mengikuti syarat dan ketentuan untuk menghasilkan pertambahan bobot ikan secara baik (Sukardi et al., 2017). Dari data penelitian yang didapatkan menjadi acuan dalam penentuan meningkatnya pertumbuhan pada setiap waktu pencahayaan terhadap lingkungan budidaya dengan melakukan perekayasaan cahaya yang diberikan pada saat malam hari.

Pada setiap pelakuan yang dapat dilihat pada Tabel 3, dengan adanya tiga perbedaan huruf, namun hanya pada $\mathrm{P} 2$ dan P3 didapatkan hasil dengan huruf yang sama. Dari hasil tersebut perekayasaan cahaya pada lingkungan budidaya, ikan memiliki respon pertumbuhan yang berbeda-beda. Jika hasil dibandingkan dengan kontrol (P1), artinya perekayasaan dengan memberikan cahaya ini memberikan efek yang positif bagi peningkatan pertumbuhan ikan.

Berdasarkan penelitian yang dilakukan oleh Suprihatin (1998), menyatakan pencahayaan 21 jam merupakan pertumbuhan terbaik baik bagi ikan, sama hal nya dengan penelitian yang telah dilakukan dengan pencahayaan selama 24 jam menggunakan intensitas cahaya sebesar 314 lux menghasilkan pertumbuhan yang paling baik dari perlakuanperlakuan yang lain. Apabila dilihat dari setiap perlakuan dapat dinyatakan bahwa semakin lama waktu pencahayaan yang diberikan maka semakin besar peningkatan pertumbuhan ikan bawal yang dihasilkan.

Dilihat dari hasil tersebut dapat dikaitkan dengan adanya proses dari retensi protein pada ikan yang dipelihara. Retensi protein merupakan suatu proses penyerapan makanan yang terkandung didalam pakan (protein) yang berfungsi dalam pembentukan daging. Ikan bawal yang diberikan cahaya yang lebih lama memiliki retensi protein yang lebih tinggi dibandingkan dengan ikan yang diberikan cahaya lebih sedikit, dengan demikian apabila retensi protein semakin baik maka pembentukan daging pada ikan akan lebih cepat (Subekti, 2016).

Rekayasa lingkungan budidaya pada penelitian ini dengan intensitas cahaya sebesar 314 lux pada setiap perlakuan, hal ini berkaitan dengan adanya tingkat sensitivitas penglihatan ikan bawal. Berdasarkan pengamatan selama penelitian, pada saat malam hari ikan diberi makan memberikan respon yang cepat untuk memakan pakan yang diberikan. Artinya, pada intensitas tersebut ikan bawal mampu melihat pakan yang berada di permukaan air (Syam dan Satria, 2009).

Menurut Chengguo et al. (2009) ikan yang aktif disiang hari (diurnal) kemudian dipelihara dengan tidak diberikan cahaya cenderung tidak mau makan, ikan akan lebih banyak diam dan laju pengosongan lambung akan terhambat. Respon tubuh ikan cenderung akan lebih banyak menggunakan energi untuk proses perkembangan seksual dibandingkan dengan perkembangan tubuh dalam proses pertambahan sel untuk tumbuh. Ikan bawal memiliki respon yang cepat terhadap lingkungan, dari hasil pengamatan selama penelitian ikan bawal memberikan respon yang positif terhadap cahaya yang diberikan.

Makhluk hidup membutuhkan cahaya untuk melakukan aktivitas seperti mencari makan, melakukan metabolisme untuk memenuhi kebutuhan hidup ikan dalam proses pertumbuhan yang berlangsung, sehingga dapat dikaitkan dengan pertumbuhan ikan, dengan adanya pencahayaan ikan lebih banyak memberikan respon lebih cepat dari ikan yang tidak mendapatkan cahaya (Sukardi, 2017). Hal ini berkaitan dengan pengamatan selama penelitian, respon ikan pada saat diber makan pada saat malam hari pada ikan yang mendapatkan sinar pencahayaan memiliki respon makan lebih cepat dari ikan yang tidak mendapatkan cahaya.

Berdasarkan nilai rasio konversi pakan yang terdapat pada Tabel 4, rasio konversi pakan sangat erat hubungannya dengan pertumbuhan ikan yang dipelihara selama satuan waktu. Dari hasil pengamatan yang dilakukan selama penelitian, tidak terdapat sisa pakan yang harus terbuang pada perlakuan lama pencahayaan selama 24 jam. Pertumbuhan dapat terjadi jika pakan yang dikonsumsi oleh ikan memiliki efisiensi yang baik dan ketersediaan energi akan lebih besar, dengan tersedianya banyak energi maka sisa dari energi yang digunakan untuk melakukan aktivitas tubuh akan lebih banyak sehingga energi untuk pertumbuhan juga lebih besar (Setiawati et al., 2013).

Menurut penelitian yang dilakukan oleh Kelabora (2010), sintasan sangat berpengaruh terhadap kondisi kualitas air pada media budidaya yang digunakan. Terkait dengan penelitian yang dilakukan bahwa perlakuan lama pencahayaan yang diberikan tidak membuat kualitas air memburuk. Maka dapat dinyatakan bahwa lama pencahayaan yang merekayasa lingkungan budidaya ikan bawal ini memiliki kategori yang baik untuk dilakukan pada pemeliharaan ikan bawal sampai dengan pemanenan.

Menurut Jaya et al. (2013) semakin tinggi sintasan maka proses budidaya tergolong pada kondisi yang baik, sebaliknya semakin rendah nilai sintasan pada budidaya maka proses budidaya yang dilakukan tergolong pada kondisi kurang baik. Berdasarkan pernyataan tersebut perlakuan dari lama pencahayaan memiliki nilai sintasan pada kisaran diatas $90 \%$ maka dinyatakan tergolong pada keadaan yang sangat baik. Dari olahan data yang dihasilkan pada penelitian ini, bahwasanya nilai sintasan tidak memiliki hubungan erat dengan diberikannya perlakuan lama pencahayaan yang berbeda selama penelitian, dikarenakan perlakuan lama pencahayaan memberikan hasil sintasan yang tidak jauh berbeda.

Selanjutnya, pada pengamatan kualitas air yaitu DO, suhu dan $\mathrm{pH}$ memilki kisaran yang sesuai dengan toleransi hidup ikan bawal (Djarijah, 2001), dan diberikannya perekayasaan pencahayaan pada lingkungan budidaya tidak memberikan efek buruk terhadap kualitas air yang digunakan untuk pemeliharaan ikan bawal. Kualitas air merupakan hal 
yang sangat penting pada setiap tahapan kehidupan ikan (Kelabora, 2010), untuk kisaran kualitas air pada pemeliharaan ikan bawal disesuaikan dengan toleransi hidup ikan bawal (Monalisa \& Minggawati, 2010) seperti yang terdapat pada Tabel 6.

Tabel 6

Kondisi kualitas air pada pemeliharaan ikan bawal selama penelitian.

\begin{tabular}{lc}
\hline \multicolumn{1}{c}{ Parameter } & Nilai (rata-rata) \\
\hline Oksigen terlarut (DO) & $5,5 \mathrm{mg} / \mathrm{L}$ \\
Suhu & $28^{\circ} \mathrm{C}$ \\
Derajat keasaman $(\mathrm{pH})$ & 7,5 \\
\hline
\end{tabular}

\section{Kesimpulan}

Perekayasaan lingkungan dengan pemberian cahaya pada malam hari memberikan peningkatan yang signifikan bagi pertumbuhan ikan bawal air tawar (C. macropomum).

\section{Bibliografi}

Amalia, R., Hastuti, S., Sudaryono, A., 2019. Pengaruh Pemberian tepung Cacing Tanah (Lumbricus sp.) Sebagai Atraktan Dalam Pakan Terhadap Tingkat Konsumsi Pakan, Efisiensi Pakan dan Pertumbuhan Ikan Patin (Pangsius sp.). Akuakultur Tropis, 3 (1): 27-35.

Boeuf, G., Pierre Y.L.B., 1999. Does Light Have an Influence on Fish Growth. Aquaculture, 177 (1-4). Elsevier: 129-52.

Chengguo, L., Yan. S., 2009. Study on the Diurnal Changes of Net Photosynthetic Rate and the Impact Factors of Stevia rebaudiana Bertoni in Autumn. American Journal of Plant Physiology, 4(1): 18-23.

Djarijah, A.S., 2001. Budidaya Ikan Bawal. Kanisius: Yogyakarta.

Effendi, I., 2004. Pengantar Akuakultur. Penebar Swadaya. Jakarta.

Effendi, M.I., 1997. Biologi Perikanan. Yayasan Pustaka Nusatama, Yogyakarta.

Jaya, B., Agustriani, F., Isnaini., 2013. Laju Pertumbuhan dan Tingkat Kelangsungan Hidup Benih Ikan Kakap Putih (Lates calcarifer, Bloch) dengan Pemberian Pakan yang Berbeda. Maspari Journal, 5(1): 56-63.

Kelabora, D.M., 2010. Pengaruh Suhu Terhadap Kelangsungan Hidup dan Pertumbuhan Larva Ikan Mas (Cyprinus carpio). Berkala Perikanan Terubuk, 38(1): 0126-6265.

Kordik, M.G.H., 2005. Budidaya Ika Patin, Biologi, Pembenihan dan Pembesaran. Yayasan Pustaka Nusantara. Yogyakarta. 170 hal.

Kurniawan, A., Basuki. F., Nugroho. R.A., 2017. Pengaruh Pemberian Rekombinan Hormon Pertumbuhan ( $\mathrm{rGH})$ Melalui Metode Oral dengan Interval Waktu yang Berbeda Terhadap Pertumbuhan dan Kelulushidupan Benih Ikan Bawal Ikan Air Tawar. Jurnal of Aquaculture Management and Technology, 6(3): 20-29.

Monalisa, S.M., Minggawati. I., 2010. Kualitas Air Yang Mempengaruhi Pertumbuhan Ikan Nila (Oreochromis sp.) Di Kolam Beton Dan Terpal. Jurnal of Tropical Fisheries, 5(2): 526-530.

Setiawati, J.E., Tarsim, Adiputra, Y.T., Hudaidah, S., 2013. Pengaruh Penambahan Probiotik Pada Pakan dengan Dosis Berbeda Terhadap Pertumbuhan, Kelulushidupan, Efisiensi Pakan dan Retensi Protein Ikan Patin. Jurnal Rekayasa dan Teknologi Budidaya Perairan, 1(2): 23023600 .

Setyawan, P.K.F., Rejeki, S., Nugroho, R.A., 2014. Pengaruh pemberian recombinant growth hormone $(\mathrm{rGH})$ melalui metode perendaman dengan dosis yang berbeda terhadap kelulushidupan dan pertumbuhan larva ikan nila larasati (Oreochromis niloticus). Journal of Aquaculture Management and Technology, 3(2): 69-76.

Subekti, S., Arief, M., Yudha, G.C.P., 2016. Substitusi Silase Secara Kimiawi Limbah Padat Surimi Ikan Swanggi (Priacanthus maracanthus) Pada tepung Ikan Terhadap Retensi Protein dan Retensi Lemak Ikan Nila (Oreochromis niloticus). Jurnal Ilmiah Perikanan dan Kelautan, 8 (2): 77-83.

Sukardi, Yanto, S., Kadirman, 2017. Pengaruh Warna Cahaya Lampu Dan Intensitas Cahaya Yang Berbeda Terhadap Respons Benih Ikan Bandeng (Chanos chanos forskal). Jurnal Teknologi Pendidikan Pertanian, 3: 242-250.

Sulawsety, F., Chrismandha, T., Mulyana, E., 2014. Laju Pertumbuhan Ikan Mas (Cyprinus carpio L) Dengan Pemberian Pakan Lemna (Lemna perpusilla torr.) Segar Pada Kolam Sistem Aliran Tertutup. Limnotek, 21(2): 117-184.

Suprihatin, T., 1998. Pengaruh peningkatan periode waktu pencahayaan terhadap laju pertumbuhan ikan nila merah (Oreochromis sp.). Doctoral Dissertation. Universitas Diponegoro.

Syam, A.R., Satria, H., 2017. Adaptasi Fisiologis Retina Mata Dan Tingkah Laku Ikan Terhadap Cahaya. Widya Riset Perikanan Tangkap, 2(5), 215-224.

Taufiq, T., Firdus, F., Arisa, I.I., 2016. Pertumbuhan benih ikan bawal air tawar (Colossoma macropomum) pada pemberian pakan alami yang berbeda. Jurnal IImiah Mahasiswa Kelautan Perikanan Unsyiah, 1(3), 355-365.

Wirawan, A.L.P., 2015. Perbedaan Lama Penyinaran Terhadap Pertumbuhan Benih Ikan Sepat Siam (Trichopodus pectoralis). Skripsi. Departemen Budidaya Perairan Fakultas Pertanian dan Ilmu Kelautan Institut Pertanian Bogor. 